\title{
MILK YIELD DURING PROLONGED LACTATION IN MICE; EFFECT OF OVARIECTOMY
}

\author{
G. H. ZEILMAKER \\ Biological Department, The Netherlands Cancer Institute, Amsterdam
}

(Received 9th January 1969)

Prolongation of lactation beyond its natural duration has been induced in rats (Bruce, 1958, 1961; Nicoll \& Meites, 1959) and mice (Parkes, 1926; Selye \& McKeown, 1934; Fekete, 1940; Mühlbock \& Tengbergen, 1961; Zeilmaker, 1968) by regular replacement of the suckling litter.

Measurement of milk yield of mice bearing pituitary grafts and subjected to prolonged lactation, suggested that milk production occurs in a cyclic fashion (Zeilmaker, 1968).

In the present study, this phenomenon has been re-investigated using mice with or without pituitary grafts under the kidney capsule. Moreover, the effect of ovariectomy on lactation was explored and attempts were made to correlate the fluctuations in milk yield with the occurrence of oestrous cycles.

Experiments were performed with $(\mathrm{C} 3 \mathrm{H} \times 020) \mathrm{F}_{1}$ mice, caged singly. During the 2nd week of pregnancy three of the four experimental groups of animals received two syngenetic pituitary glands under the kidney capsule. After parturition (age 9 to 12 weeks), the litter size was adjusted to a total of ten. Twice weekly the suckling litter was weighed and replaced by 0 - to 2 -dayold young.

The litter-weight increase over the previous 7-day period was plotted twice weekly, each point of the curve representing the mean of two weight determinations. This procedure was followed for practical reasons because the different intervals ( 3 or 4 days) between the measurements could then be disregarded.

Four groups of lactating mice were studied: eight intact mice; nine pituitarygraft-bearing mice; sixteen pituitary-graft-bearing mice of which vaginal smears were taken during 16 weeks; and ten pituitary-graft-bearing mice ovariectomized within 3 days after parturition.

The litter growth curves (Text-fig. 1) plotted from data obtained with intact mice indicate that after about 10 weeks of prolonged lactation, there is a temporary cessation of milk production. Thereafter, milk yield, as reflected by litter growth, fluctuates.

In mice bearing pituitary grafts, a similar period of 8 to 10 weeks of continuous milk production can be observed (Text-fig. 2). Following temporary cessation of lactation, cycles with a duration of 2 to 3 weeks can clearly be distinguished. Milk yield in the graft-bearing mice is slightly greater than in the intact animals and follows a more reproducible pattern. 
In the ovariectomized mice, the period of uninterrupted milk production is prolonged and lasts about 16 weeks, after which milk production is not resumed (Text-fig. 3).

Vaginal smear records showed that the first pseudopregnancy occurring after parturition had a duration of $19 \cdot 6 \pm 0 \cdot 6$ days. The second pseudopregnancy lasted $12 \cdot 4 \pm 0 \cdot 8$ days. The average length of thirty-three pseudopregnancies occurring more than 10 weeks after parturition was $17 \cdot 1 \pm 0 \cdot 6$ days. These intervals between the oestrous periods are similar to those noticed by Selye \& McKeown (1934).

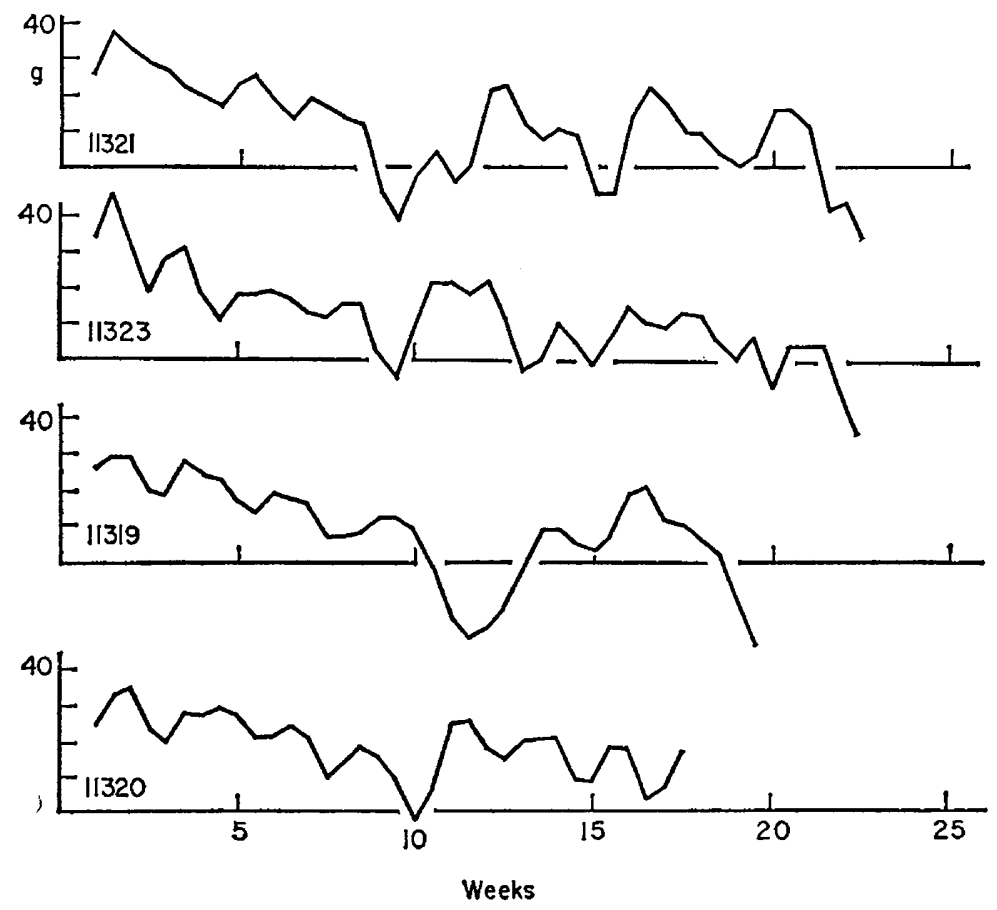

TEXT-FIG. 1. Milk yield during prolonged lactation in four intact mice. Twice weekly the litter weight gain (g) over the previous 7-day period is plotted. More or less continuous milk production during the first 8 to 10 weeks; thereafter milk production fluctuates.

Vaginal oestrus, occurring during the period of cyclic fluctuations in milk yield, was recorded twenty-five times in sixteen animals. The average daily litter-weight increase during the 4- to 7-day period preceding vaginal oestrus was $2 \cdot 05 \pm 0 \cdot 19$, whereas during the 4 - to 7 -day period following oestrus litter growth averaged $3.52 \pm 0.22 \mathrm{~g} /$ day. When data of individual mice were compared it appeared that in sixteen instances, less milk was produced before ovulation than thereafter. No difference was found in seven cases and more milk was produced in two cases, the difference, however, being very small.

It could well be that, during the period of cyclic fluctuations in milk yield, ovulations occur shortly after a period of minimal milk yield. We consider, however, that our data and those mentioned earlier (Zeilmaker, 1968) are not 
a definite proof since, unfortunately, the vaginal smear data cover a period which includes only about two lactation cycles per animal. In rats, the occurrence of oestrous cycles did not have a detectable effect on milk yield (Bruce, 1961).

The first effect induced by the ovary is an inhibitory one, occurring 8 to 10 weeks post partum. This inhibitory influence is probably the result of an action
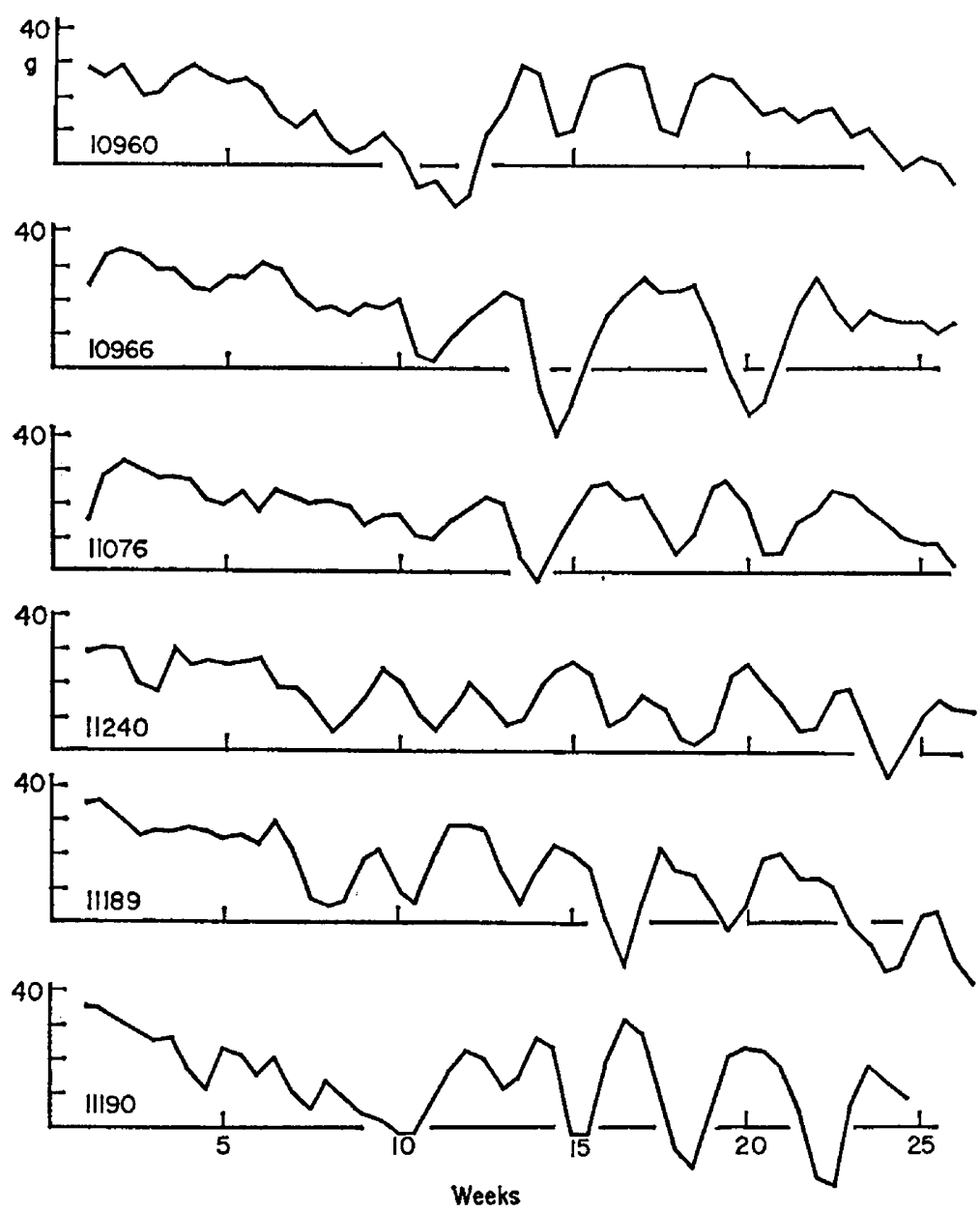

TEXT-FIG. 2. Milk yield during prolonged lactation in six pituitary-graft-bearing mice. During the first 7 to 12 weeks, milk is produced continuously. After this period, 'lactation cycles' with a duration of 2 to 3 weeks occur.

of ovarian hormones at the level of the mammary gland. An effect at pituitary gland level is unlikely since an exogenous source of prolactin is present in the graft-bearing mice. Moreover, the suckling stimulus is continuously exerted. Also, other studies have indicated that, in the rat and the rabbit, a combination of oestrogen and progesterone effectively suppresses the lactogenic activity of 
prolactin, at the level of the mammary gland (Desclin, 1952; Meites \& Sgouris, 1954).

It is clear that a morphological analysis of the mammary gland is necessary before it can be concluded whether resumption of lactation can occur as a result of renewed secretory activity of the existing alveolar apparatus or occurs concurrently with the formation of new mammary gland elements. The latter phenomenon has been observed by Ota \& Yokoyama (1965) following temporary litter removal in lactating rats. It should be pointed out, however, that litter removal causes severe damage to the alveolar system (Williams, 1941 ; Zeilmaker, 1968).
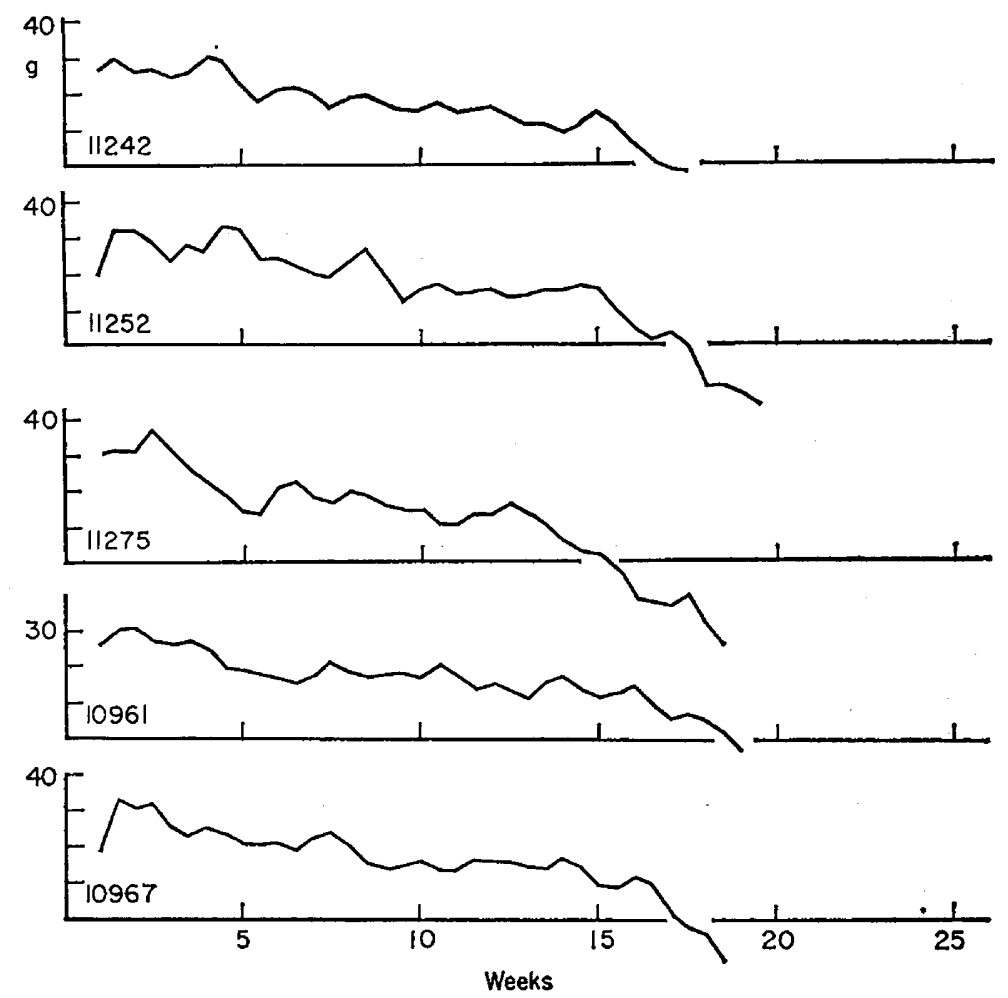

TExT-FIC. 3. Milk yield during prolonged lactation in five ovariectomized pituitarygraft-bearing mice. Continuous milk production during 15 or more weeks; thereafter milk production ceases.

\section{REFERENCES}

BRUCE, H. M. (1958) Suckling stimulus and lactation. Proc. R. Soc. B, 149, 421.

BRUCE, H. M. (1961) Observations on the suckling stimulus and lactation in the rat. F. Reprod. Fert. $2,17$.

Desclin, L. (1952) Recherches sur le déterminisme des phénomènes de sécrétion dans la glande mammaire du rat. Annls Endocr. 13, 120.

Fekete, E. (1940) Observations on three functional tests in a high-tumor and a low-tumor strain of mice. Am. F. Cancer, 38, 234.

Merres, J. \& Sgouris, J. T. (1954) Effects of altering the balance between prolactin and ovarian hormones on initiation of lactation in rabbits. Endocrinology, 55, 530. 
Mühlbock, O. \& van Ebbenhorst Tengbergen, W. (1961) Functional components in the genesis of mammary cancer in mice, pregnancy and lactation. Acta Un. int. Cancr. 17, 88.

Nicoll, C. S. \& Mertes, J. (1959) Prolongation of lactation in the rat by litter replacement. Proc. Soc. exp. Biol. Med. 101, 81.

Ota, K. \& Yokoyama, A. (1965) Resumption of lactation by suckling in lactating rats after removal of litters. 7. Endocr. 33, 185.

PARKes, A. S. (1926) Observations on the oestrous cycle of the albino mouse. Proc. R. Soc. B, 100, 151 .

Selye, H. \& MaKeown, T. (1934) Further studies on the influence of suckling. Anat. Rec. 60, 323.

Williams, W. L. (1941) The effect of non-suckling and the non-removal of milk upon individual mammary glands in the lactating mouse. Yale F. Biol. Med. 14, 201.

Zeilmaker, G. H. (1968) Prolonged lactation in mice and its effect on mammary tumorigenesis. Int. 7. Cancer, 3, 291. 